\title{
GRADUATES' PERCEPTION ON THE IMPORTANCE OF SPECIAL JOB MARKET IN STATE VOCATIONAL HIGH SCHOOLS IN LANGSA CITY
}

\author{
Al Fatahillah \\ Universitas Negeri Yogyakarta \\ Mochamad Bruri Triyono \\ Universitas Negeri Yogyakarta
}

\begin{abstract}
This study aims to determine the perceptions of graduates of state vocational high schools in Langsa City on the performance of Special Job Market in vocational high schools based on the aspects of (1) Special Job Market performance; (2) role of Special Job Market; (3) Special Job Market service; and (4) the success of the Special Job Market. This study is quantitative research employing a descriptive approach. The population of the research is 365 graduates tracked through the Special Job Market of four vocational schools in Langsa City in 2007/2008. From the population, 15\% were taken for the samples of the study, so the number of respondents is 55 graduates. The result of the research shows that: (1) the percentage of Special Job Market performance aspect is $58.54 \%$ with "quite satisfied" criteria; (2) the percentage of role of Special Job Market aspect is 59.14\% with "quite satisfied" criteria; (3) the percentage of Special Job Market service aspect is $51.02 \%$ with "quite satisfied" criteria; and (4) the percentage of the success of the Special Job Market aspect is $51.17 \%$ with "quite satisfied" criteria.
\end{abstract}

Keywords: graduates' perception, special job market, vocational high school

Permalink: http://dx.doi.org/10.21831/jpv.v9i2.26361

Contact Al Fatahillah alfatahillah91@gmail.com

Department of Vocational Education, Graduate School of Universitas Negeri Yogyakarta

Jl. Colombo No. 1, Karangmalang, Depok, Sleman 55281, Yogyakarta, Indonesia 


\section{INTRODUCTION}

Vocational education is an education which is aimed at preparing skilled, ready, as well as productive human resources in specific fields. According to Fedorov and Tretyakova (2016, p. 9810), vocational education is required to have instructors fully involved in providing education and training in encouraging the vocational education system. Instructors in vocational education must be able to plan education that is disciplined and capable of being explained logically or according to facts.

Vocational high school is one of the educational institutions which aims to produce graduates who are ready to work. Graduation's distribution is one of the provisions and implementation of the Vocational curriculum, even as a benchmark for the success of vocational high schools, as stated in the Regulation of the Minister of Education and Culture No. 34 of 2018 concerning the national standard of education in Vocational High School (VHS) or Sekolah Menengah Kejuruan (SMK) and also Islamic Vocational High Schools: VHS/Islamic VHS is part of the national education system which has the aim of vocational education, that is, producing skilled workers who have the ability in accordance with the demands of the business/industrial world, and are able to develop their potential in adopting and adapting to the development of science, technology, and art. The existence of standards that regulate vocational secondary schools is expected to be able to encourage as well as strengthen the potential and guarantee of graduates with the quality that is included in the job market qualifications.

Of the existing standards for secondary education in Indonesia, the government has launched the Vocational High School revitalization program in accordance with the Presidential Instruction No. 9 of 2016. In the steps or efforts to revitalize the vocational school, there needs to be a curriculum alignment supported by the role of stakeholders, the role of the world of work (industrial world of business) in the hope that graduates have competencies in accordance with the relevant fields. Vocational curriculum dissemination is in accordance with the Presidential Instruction No. 9 of 2016 written in the vocational high school revitalization strategy that the flow of the vocational school curriculum alignment can be started from the ability of students to be supported by vital needs of education facilities and infrastructure, while in the work world identification of competency needs which is in accordance with vocational high school. If both of them have been implemented, then vocational schools and the business world in the industry can harmonize the Vocational High School curriculum.

Comprehension of the type of command or assignment of a work which is related to the development of knowledge in education is called vocational education (Sudira, 2016). Further, Pavlova (2009) said that the objectives of the tradition of vocational education include: traditionally, direct preparation for work was the primary goal of vocational education. It was perceived as providing specific training that was reproductive and based on the teachers' instruction, with the intention to develop an understanding of a particular industry, comprising the specific skills or tricks of the trade. Students' motivation was seen to be engendered by the economic benefit to them in the future. Competency-based training was chosen by most governments in western societies as a model for vocational education. Juridically, the basic definition of vocational education in Indonesia is stated in the Law of Republic of Indonesia No. 20 of 2003 concerning National Education System that vocational education is secondary education to prepare students to work in accordance with certain fields. Vocational education will be efficient if the environment is provided in accordance with the conditions of the world of work, training held in vocational education will be efficient if the tasks given have similarities with operations in the workforce or industry, and the need for habitual behavior applied in the workforce or industry.

In carrying out its roles and functions, vocational high schools (VHSs) certainly need a unit called Special Job Market (Bursa Kerja Khusus or BKK), as structured in Figure 1, to connect graduates to the world of work and industry. Special Job Market is an implementing unit that provides services and information on job vacancies, executors of marketing, distribution, and placement of workers. 


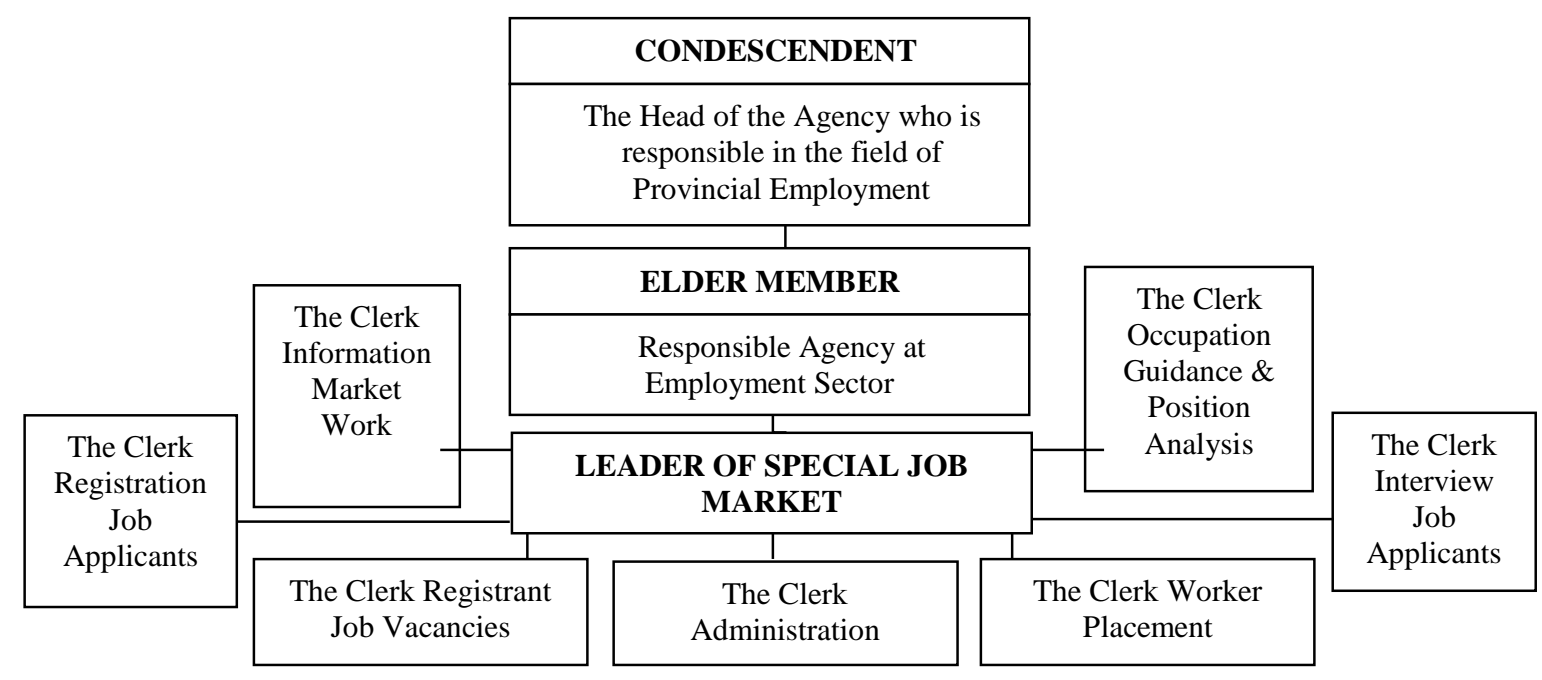

Figure 1. The Special Job Market Organizational Structure (Source: Department of Manpower and Transmigration, 2012)

As stated in the Regulation of the Minister of Manpower No. 39 of 2016 concerning manpower placement, Special Job Market is an institution which is formed in secondary, high education, and job training institutions that carry out work placements for graduates. Furthermore, the regulation also explains that the scope of Special Job Market includes: (1) registration and data collection of job seekers who have completed their education or training; (2) registering job opportunity vacancies; (3) giving guidance to job seekers (graduates) to know their talents, interests, and also abilities according to the needs of labor users or for independent businesses; (4) offers to the labor users regarding the availability of labor; (5) implementation of verification as a follow-up of the delivery and placement that has been carried out; (6) holding a Job Exhibition (Job fair).

Perception is the responding, meaning, picturing, or interpretation of what is seen, heard, or felt by the senses in the form of attitudes, opinions, and behavior. Slameto (2010) concludes that perception is a process that involves the entry of messages or information into the human brain, through human perception continuously in contact with the environment. This relationship is done through the senses, namely the sense of sight, listener, touch, taste, and smell. Sarwono (2012) states that perception takes place when receiving a stimulus from the outside world that is captured by the organs of his aid, which then enters the brain.
The Special Job Market in carrying out its programs certainly requires assessments from parties involved in it, including graduates. The assessment of graduates in the form of perception can be one material to evaluate the performance itself.

Langsa City has ten public and private vocational high schools which are spread throughout the city. However, only four of them have the Special Job Market, namely, SMK N 1 Langsa, SMK N 2 Langsa, SMK N 3 Langsa, and SMK N 4 Langsa. The data of the graduates of the schools are clearly presented in Table 1.

Table 1. Graduate Search Data

\begin{tabular}{ccc}
\hline School Name & $\begin{array}{c}\text { Number of } \\
\text { Graduates }\end{array}$ & Working \\
\hline SMK N 1 Langsa & 175 & 63 \\
SMK N 2 Langsa & 383 & 169 \\
SMK N 3 Langsa & 213 & 113 \\
SMK N 4 Langsa & 38 & 20 \\
Total & 809 & 365 \\
\hline
\end{tabular}

(Source: Observation data, 2019)

Table 1 shows that the absorbed graduates' scores are very low, which is only about $45 \%$ of the total graduates. Therefore, it is necessary to conduct research that aims to determine the perceptions of graduates on Special Job Market performance. It is expected that the results of this research will be useful as an evaluation material for related parties to improve the absorption of vocational schools graduates through the Special Job Market. 


\section{RESEARCH METHOD}

This study is a quantitative research employing a descriptive approach. It was conducted using a questionnaire which was filled out by the graduates of SMKN 1 Langsa, SMKN 2 Langsa, SMKN 3 Langsa, and also SMKN 4 Langsa of the academic year of 2007/ 2008, who had worked through the Special Job Market. Because it was constrained by great distances, the researchers sent the questionnaires online to the graduates then analyzed it. The population was 55 graduates who were obtained through the sampling method as much as $15 \%$ of the total graduates. Data analysis was carried out by three steps: (1) collecting respondents' data; (2) analyzing the data by describing the collected data; (3) presenting data in a visual form.

\section{RESULTS AND DISCUSSION}

\section{Results}

Based on Table 2, it can be explained that: (1) for the indicator of Special Job Market is an institution to bring together job seekers and users of labor (vocational graduates), there are 24 respondents (43.64\%) who said they are satisfied and 31 respondents $(56.36 \%)$ who said they are very satisfied; (2) for the indicator of Special Job Market performance in schools helps me to find relevant job information, 26 respondents $(47.27 \%)$ said they are satisfied, and 29 respondents $(52.73 \%)$ said they are very satisfied; (3) for the indicator of Special Job Market is able to carry out obligations and programs in the working distribution, 31 respondents $(56.36 \%)$ said they are satisfied and 24 respondents $(43.64 \%)$ said they are very satisfied; (4) for the indicator of Special Job Market is able to reduce the waiting period for graduates to get jobs, 24 respondents (43.64\%) said they are satisfied, and 31 respondents $(56.36 \%)$ said they are very satisfied; (5) for the indicator of Special Job Market utilizes information technology to support services, 27 respondents $(49.09 \%)$ said they are satisfied, and 28 respondents $(50.91 \%)$ said they are very satisfied; (6) for the indicator of Special Job Market provides good information services on employment, 29 respondents $(52.73 \%)$ said they are satisfied and 26 respondents (47.27\%) said they are very satisfied.

Table 2. Special Job Market Performance Aspect

\begin{tabular}{|c|c|c|c|c|c|}
\hline No & Indicator & $\begin{array}{l}\text { Disatisfied } \\
\text { Percentage } \\
\quad(\%)\end{array}$ & $\begin{array}{c}\text { Quite } \\
\text { Satisfied } \\
\text { Percentage } \\
(\%)\end{array}$ & $\begin{array}{l}\text { Satisfied } \\
\text { Percentage } \\
\quad(\%)\end{array}$ & $\begin{array}{c}\text { Very } \\
\text { Satisfied } \\
\text { Percentage } \\
\quad(\%)\end{array}$ \\
\hline 1 & $\begin{array}{l}\text { Special Job Market is an } \\
\text { institution to bring together job } \\
\text { seekers and users of labor } \\
\text { (vocational graduates) }\end{array}$ & 0 & 0 & 43.64 & 56.36 \\
\hline 2 & $\begin{array}{l}\text { Special Job Market performance } \\
\text { in schools, helps me to find } \\
\text { relevant job information }\end{array}$ & 0 & 0 & 47.27 & 52.73 \\
\hline 3 & $\begin{array}{l}\text { Special Job Market is able to } \\
\text { carry out obligations and } \\
\text { programs in the working } \\
\text { distribution }\end{array}$ & 0 & 0 & 56.36 & 43.64 \\
\hline 4 & $\begin{array}{l}\text { Special Job Market is able to } \\
\text { reduce the waiting period for } \\
\text { graduates to get jobs }\end{array}$ & 0 & 0 & 43.64 & 56.36 \\
\hline 5 & $\begin{array}{l}\text { Special Job Market utilizes } \\
\text { information technology to } \\
\text { support services }\end{array}$ & 0 & 0 & 49.09 & 50.91 \\
\hline 6 & $\begin{array}{l}\text { Special Job Market provides } \\
\text { good information services on } \\
\text { employment }\end{array}$ & 0 & 0 & 52.73 & 47.27 \\
\hline
\end{tabular}

(Source: Result of data analysis, 2019) 
Based on Table 3, it can be explained as follows. (1) For the indicator of Special Job Market supports the absorption of graduates in the relevant workforce, there are two respondents (3.64\%) who said they are quite satisfied, 21 respondents $(38.18 \%)$ who said they are satisfied, and 32 respondents $(58.18 \%)$ who said they are very satisfied. (2) For the indicator of Special Job Market have provided effective career guidance to students and graduates, 17 respondents (30.91\%) said they are satisfied and 38 respondents (69.09\%) said they are very satisfied. (3) For the indicator of Special Job Market carries out data collection and classification of students based on physical, age, grades, majors and sex periodically and have been submitted to students and graduates, 25 respondents $(45.45 \%)$ said they are satisfied and 30 respondents $(54.55 \%)$ said they are very satisfied. (4) For the indicator of Special Job Market provides services by presenting a consulting firm from the company as a provision to enter the workforce, 20 respondents $(36.36 \%)$ said they are satisfied and 35 respondents $(63.64 \%)$ said they are very satisfied. (5) For the indicator of Special Job Market has held seminars, workshops, or training on career management and strategies in finding information or job vacancies, 34 respondents $(61.82 \%)$ said they are satisfied and 21 of them $(38.18 \%)$ said they are very satisfied. (6) For the indicator of Special Job Market in schools has carried out regular recruitment of graduates (annually), 28 respondents $(50.91 \%)$ said they are satisfied and 27 $(49.09 \%)$ said they are very satisfied.

Table 3. Role of Special Job Market Aspect

\begin{tabular}{|c|c|c|c|c|c|}
\hline No & Indicator & $\begin{array}{l}\text { Disatisfied } \\
\text { Percentage } \\
\qquad(\%)\end{array}$ & $\begin{array}{c}\text { Quite } \\
\text { Satisfied } \\
\text { Percentage } \\
(\%)\end{array}$ & $\begin{array}{l}\text { Satisfied } \\
\text { Percentage } \\
\quad(\%)\end{array}$ & $\begin{array}{l}\text { Very Satisfied } \\
\text { Percentage } \\
(\%)\end{array}$ \\
\hline 1 & $\begin{array}{l}\text { Special Job Market supports the } \\
\text { absorption of graduates in the } \\
\text { relevant workforce }\end{array}$ & 0 & 3.64 & 38.18 & 58.18 \\
\hline 2 & $\begin{array}{l}\text { Special Job Market have } \\
\text { provided effective career } \\
\text { guidance to students and } \\
\text { graduates }\end{array}$ & 0 & 0 & 30.91 & 69.09 \\
\hline 3 & $\begin{array}{l}\text { Special Job Market carry out data } \\
\text { collection and classification of } \\
\text { students based on physical, age, } \\
\text { grades, majors and sex } \\
\text { periodically and have been } \\
\text { submitted to students and } \\
\text { graduates }\end{array}$ & 0 & 0 & 45.45 & 54.55 \\
\hline 4 & $\begin{array}{l}\text { Special Job Market provides } \\
\text { services by presenting a } \\
\text { consulting firm from the } \\
\text { company as a provision to enter } \\
\text { the workforce }\end{array}$ & 0 & 0 & 36.36 & 63.64 \\
\hline 5 & $\begin{array}{l}\text { Special Job Market has held } \\
\text { seminars, workshops, or training } \\
\text { on career management and } \\
\text { strategies in finding information } \\
\text { or job vacancies }\end{array}$ & 0 & 0 & 61.82 & 38.18 \\
\hline 6 & $\begin{array}{l}\text { Special Job Market in schools has } \\
\text { carried out regular recruitment of } \\
\text { graduates (annually) }\end{array}$ & 0 & 0 & 50.91 & 49.09 \\
\hline
\end{tabular}

(Source: Result of data analysis, 2019) 
Based on Table 4, it can be explained that (1) on the indicator of Special Job Market has provided information services in the form of job fair, recruitment, assessment, training career, and professional development, 16 respondents $(29.09 \%)$ said they are satisfied, and 39 of them $(70.91 \%)$ said they are very satisfied. (2) On the indicator of Special Job Market helps identify skills and abilities for suitable jobs, 20 respondents $(36.36 \%)$ said they are satisfied, and 35 others $(63.64 \%)$ said they are very satisfied. (3) On the indicator of Special Job Market helps in building skills to get a job, 21 respondents $(38.18 \%)$ said they are satisfied and 34 respondents $(61.82 \%)$ said they are very satisfied. (4) On the indicator of Special Job Market helps send the job application file to the desired company or workplace, 23 respondents $(41.82 \%)$ said they are satisfied, and 32 respondents $(58.18 \%)$ said they are very satisfied. (5) On the indicator of Special Job Market builds intensive communication with graduates, 30 respondents $(54.55 \%)$ said they are satisfied, and 25 respondents $(45.45 \%)$ said they are very satisfied. (6) On the indicator of Special Job
Market in schools has complete and adequate infrastructure, 29 respondents $(52.73 \%)$ said they are satisfied, and 26 respondents (47.27\%) said they are very satisfied. (7) On the indicator of Special Job Market conducts data collection and tracking of graduates, there are 26 respondents $(47.27 \%)$ who said they are satisfied, and $29(52.73 \%)$ who said they are very satisfied.

Based on Table 5, it can be explained that (1) on the indicator of Career services and vocational high schools graduate work placements have been achieved, there are 24 respondents $(43.64 \%)$ who said they are satisfied and 31 respondents $(56.36 \%)$ who said they are very satisfied. (2) On the indicator of Vocational high schools graduates in accordance with the job market qualifications (workforce), 28 respondents $(50.91 \%)$ said they are satisfied and 27 respondents $(49.09 \%)$ said they are very satisfied. (3) On the indicator of Special Job Market is able to help the absorption of vocational high schools graduates in the job market, 24 respondents $(43.64 \%)$ said they are satisfied and 31 respondents $(56.36 \%)$ said very satisfied. (4) On the indicator of Special Job Market

Table 4. Special Job Market Service Aspect

\begin{tabular}{|c|c|c|c|c|c|}
\hline No & Indicator & $\begin{array}{l}\text { Disatisfied } \\
\text { Percentage } \\
\quad(\%)\end{array}$ & $\begin{array}{c}\text { Quite } \\
\text { Satisfied } \\
\text { Percentage } \\
(\%)\end{array}$ & $\begin{array}{l}\text { Satisfied } \\
\text { Percentage } \\
\quad(\%)\end{array}$ & $\begin{array}{l}\text { Very Satisfied } \\
\text { Percentage } \\
(\%)\end{array}$ \\
\hline 1 & $\begin{array}{l}\text { Special Job Market has provided } \\
\text { information services in the form } \\
\text { of jobfair, recruitment, } \\
\text { assessment, training career, and } \\
\text { professional development }\end{array}$ & 0 & 0 & 29.09 & 70.91 \\
\hline 2 & $\begin{array}{l}\text { Centre helps identify skills and } \\
\text { abilities for suitable jobs }\end{array}$ & 0 & 0 & 36.36 & 63.64 \\
\hline 3 & $\begin{array}{l}\text { Special Job Market helps in } \\
\text { building skills to get a job }\end{array}$ & 0 & 0 & 38.18 & 61.82 \\
\hline 4 & $\begin{array}{l}\text { Special Job Market helps send the } \\
\text { job application file to the desired } \\
\text { company or workplace }\end{array}$ & 0 & 0 & 41.82 & 58.18 \\
\hline 5 & $\begin{array}{l}\text { Special Job Market builds } \\
\text { intensive communication with } \\
\text { graduates }\end{array}$ & 0 & 0 & 54.55 & 45.45 \\
\hline 6 & $\begin{array}{l}\text { Special Job Market in schools has } \\
\text { complete and adequate } \\
\text { infrastructure }\end{array}$ & 0 & 0 & 52.73 & 47.27 \\
\hline 7 & $\begin{array}{l}\text { Special Job Market conducts data } \\
\text { collection and tracking of } \\
\text { graduates }\end{array}$ & 0 & 0 & 47.27 & 52.73 \\
\hline
\end{tabular}

(Source: Result of data analysis, 2019) 
is able to establish cooperation with the industrial world of business (workforce), 20 respondents $(36.36 \%)$ said they are satisfied and 35 respondents $(63.64 \%)$ said they are very satisfied. (5) On the indicator of Special Job Market is able to harmonize learning between the workforce and school, there are 17 respondents (30.91\%) who said they are satisfied and 38 respondents $(69.09 \%)$ who said they are very satisfied. (6) On the indicator of Special Job Market is able to provide soft skills as a provision to enter the workforce, 21 respondents $(38.18 \%)$ said they are satisfied and 34 respondents $(61.82 \%)$ said they are very satisfied. (7) On the indicator of Special Job Market is able to increase the insight to students/vocational graduates with the workforce, so graduates can choose opportunities according to their competencies, 24 respondents (43.64\%) said they are satisfied, and 31 respondents $(56.36 \%)$ said they are very satisfied.

After the data were analyzed, the percentage in Table 6 and the average results of graduates' perception in Figure 2 are obtained. Table 6 shows that the performance of the Special Job Market of Vocational High Schools in Langsa City is in the "Quite Satisfied" criteria. It is an obligation for the parties concerned to improve performance in order to achieve the Special Job Market goals as determined.

Table 5. The Success of the Special Job Market Aspect

\begin{tabular}{|c|c|c|c|c|c|}
\hline No & Indicator & $\begin{array}{c}\text { Disatisfied } \\
\text { Percentage } \\
(\%)\end{array}$ & $\begin{array}{c}\text { Quite } \\
\text { Satisfied } \\
\text { Percentage } \\
\quad(\%)\end{array}$ & $\begin{array}{l}\text { Satisfied } \\
\text { Percentage } \\
\quad(\%)\end{array}$ & $\begin{array}{c}\text { Very Satisfied } \\
\text { Percentage } \\
(\%)\end{array}$ \\
\hline 1 & $\begin{array}{l}\text { Career services and } \\
\text { vocational high schools } \\
\text { graduate work placements } \\
\text { have been achieved }\end{array}$ & 0 & 0 & 43.64 & 56.36 \\
\hline 2 & $\begin{array}{l}\text { Vocational high schools } \\
\text { graduates in accordance } \\
\text { with the job market } \\
\text { qualifications (workforce) }\end{array}$ & 0 & 0 & 50.91 & 49.09 \\
\hline 3 & $\begin{array}{l}\text { Special Job Market is able } \\
\text { to help the absorption of } \\
\text { vocational high schools } \\
\text { graduates in the job } \\
\text { market }\end{array}$ & 0 & 0 & 43.64 & 56.36 \\
\hline 4 & $\begin{array}{l}\text { Special Job Market is able } \\
\text { to establish cooperation } \\
\text { with the industrial world } \\
\text { of business (workforce) }\end{array}$ & 0 & 0 & 36.36 & 63.64 \\
\hline 5 & $\begin{array}{l}\text { Special Job Market is able } \\
\text { to harmonize learning } \\
\text { between the workforce } \\
\text { and school }\end{array}$ & 0 & 0 & 30.91 & 69.09 \\
\hline 6 & $\begin{array}{l}\text { Special Job Market is able } \\
\text { to provide soft skills as a } \\
\text { provision to enter the } \\
\text { workforce }\end{array}$ & 0 & 0 & 38.18 & 61.82 \\
\hline 7 & $\begin{array}{l}\text { Special Job Market is able } \\
\text { to increase the insight to } \\
\text { students / vocational } \\
\text { graduates with the } \\
\text { workforce, so graduates } \\
\text { can choose opportunities } \\
\text { according to their } \\
\text { competencies }\end{array}$ & 0 & 0 & 43.64 & 56.36 \\
\hline
\end{tabular}

(Source: Result of data analysis, 2019) 
Table 6. Perception of Graduates on the Importance of Career Center of State Vocational High Schools in Langsa City

\begin{tabular}{clcc}
\hline No & \multicolumn{1}{c}{ Aspect } & Percentage (\%) & Criteria \\
\hline 1 & Special Job Market Performance & 58.54 & Quite Satisfied \\
2 & Role of Special Job Market & 59.14 & Quite Satisfied \\
3 & Special Job Market Service & 51.02 & Quite Satisfied \\
4 & The Success of the Special Job Market & 51.17 & Quite Satisfied \\
\hline
\end{tabular}

(Source: Result of data analysis, 2019)

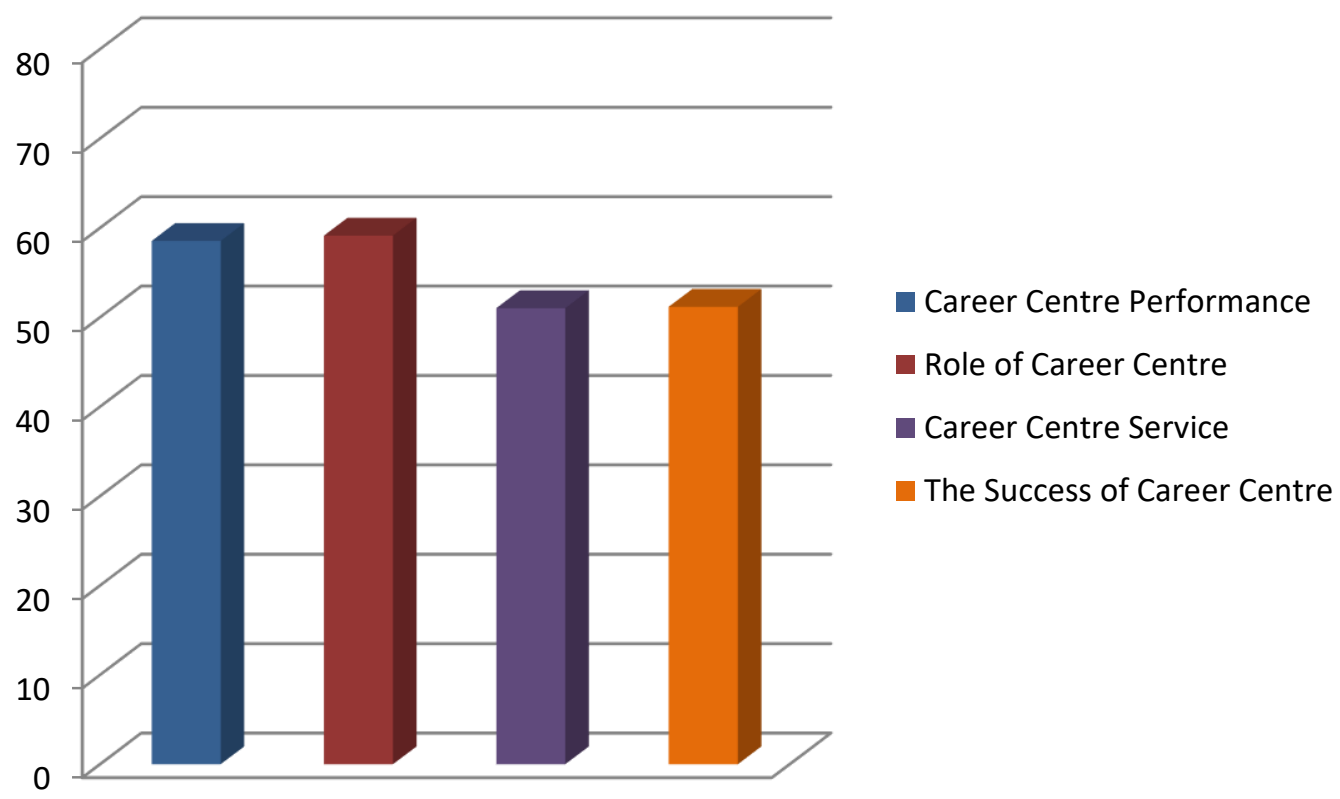

Figure 2. Average Results of Graduates' Perception of Special Job Market (Source: Result of data analysis, 2019)

\section{Discussion}

Perception is an individual's assessment of something; it can also be said that perception is a process used by individuals to manage and interpret their sensory impressions in order to give meaning to their environment. Perception can be positive (good) or negative (not good). Good perception is formed from someone's observations of something that feels good. Similarly, negative perceptions as well. Thus, it can be concluded that someone's perception can be an indicator of judgment about someone or something. A research conducted by Yazid and Ridwan (2017) shows that the positive perception of female students in viewing the development of trends in Muslim clothing affects the rise of female Muslim-dressed students, even though this is not required at institutions where they studying.

Next, Ramadhan and Soenarto (2015) conclude that students' perceptions of teacher teaching competence, parenting patterns, moti- vation for student achievement, completeness of facilities practice infrastructure, and vocational theory learning achievement are directly proportional to student learning outcomes themselves. In building a positive perception of its graduates, the Special Job Market must certainly consider the components that are the main indicators of the success of the Special Job Market in channeling graduates. Istianyani (2012) states there are several Special Job Market services that can increase the absorption of graduates into the workforce, including (1) employment information services; (2) job fair; (3) recruitment; (4) assessment; (5) training, career and professional development, and (6) graduate relations. Pambayun and Wagiran (2014) said that in order to realize its purpose, Special Job Market has to (a) optimize job hunting activities so that existing job vacancies can be absorbed and conveyed to students and graduates to the maximum both in terms of quantity and relevance; (b) expand and strengthen cooperation networks with the business world and 
the industrial world and other stakeholders so that the distribution and placement of graduates can run more broadly and optimally; (c) optimize career guidance activities for students both individually and classically to improve students' ability to choose and develop their careers, and can align student preferences with existing labor needs.

In line with that opinion, Septiningrum (2017) states that (1) Special Job Market needs to offer/promote graduates to the business world/industrial world by means of the Special Job Market. It can be done by registering graduates who have not yet gotten a job, then Special Job Market recommends to the business world/industrial world who open job openings according to the skills competencies possessed by graduates, so that more graduates are channeled through the Special Job Market; (2) Special Job Market should concern more on the order of the administration, because there are still administrations that have not been made. It can be done by creating a chart of organizational structure and graduates' data that are channeled through Special Job Market and a database of companies in collaboration with the Special Job Market.

Ridawati (2017) states that to achieve its objectives, preferably (1) the Chairperson of the Special Job Market should have participated in Technical Guidance as the manager of the Special Job Market so that he is able to understand the duties as manager of the Special Job Market; (2) the Special Job Market personnel should be young, so they have high morale and mobility; (3) the Special Job Market managers must be committed to developing the Special Job Market; (4) the principal must support all Special Job Market activities by providing dispositions and dispensations for Special Job Market managers to abandon teaching assignments because they have to negotiate with the business and industry; (5) the principal must also have an open attitude with the business world and industry; (6) students must have a relatively good, obedient, and ethical character; and (7) the physical criteria of the child must be in accordance with the needs of the company because they have been prepared since the selection of new student admissions. Judging from the aspects of facilities and infrastructure, achieving the Special Job Market program objectives is supported by factors: (1) adequate internet access; (2) adequate commu- nication tools; (3) office stationery and adequate documentation tools; and (4) school cars that can be used as operational vehicles for Special Job Market activities. In terms of financing aspects, the achievement of the Special Job Market program is supported by (1) funding opportunities for School Operational Costs (Bantuan Operasional Sekolah or BOS) for the management of Special Job Market, (2) the existence of operational assistance from industrial partners, and (3) the existence of participation from parents through committee contributions.

The results of a research conducted by 'Afif (2017) produce several recommendations to the vocational high schools: (1) vocational high schools need to pay more attention to activities in order to establish work readiness for students, one of which is the formation of work readiness such as physical sports activities; (2) vocational high schools need to increase the planting of work readiness to students in each learning process, so students are interested in participating in Special Job Market recruitment and are ready to be placed to work outside the area; (3) vocational high schools need to maximize counseling in the form of career guidance to provide students with knowledge about knowledge to face competition in the world of work; (4) improve service and renewal of employment information to students and graduates through information boards, social media or announced in schools so that every student knows that information; (5) increase promotion with the industrial world as a step to expand the network of cooperation with industry and improve cooperation with industry in the field of recruitment and placement of prospective workers; (6) increase activities similar to recruitment or placement of prospective workers in the industry; (7) increase the effectiveness of activities that can strengthen relationships with graduates and involve graduates in school activities; (8) maximize the search for graduates and create a group of graduate ties as a medium for communication with graduates intensively; (9) evaluate regularly as monitoring the implementation of Special Job Market activities; (10) schools need to pay more attention to the feedback made by the Special Job Market to schools as a recommendation to improve the student formation process to meet industry expectations. 


\section{CONCLUSION}

The vocational high school graduates' perception towards the existing Special Job Market is still quite good. It can be seen from the research results that reveal the graduates' perception is included in "Quite Satisfied" criteria. However, it would be nice if the Special Job Market's performance was further enhanced. In accordance with its objectives, each VHS should have its own Special Job Market to realize the vision and mission itself.

\section{REFERENCES}

'Afif, M. N. (2017). Evaluasi penyelenggaraan Bursa Kerja Khusus (BKK) di SMK Muhammadiyah 1 Bantul. Thesis. Universitas Negeri Yogyakarta.

Department of Manpower and Transmigration. (2012). Petunjuk teknis Bursa Kerja Khusus. Jakarta: Department of Manpower and Transmigration of Republic of Indonesia.

Fedorov, V. A., \& Tretyakova, N. V. (2016). The development of vocational pedagogical education in Russia (Organizational and Pedagogical Aspect). International Journal of Environmental \& Science Education, 11(17), 9803-9818. Retrieved from http://www.ijese.net/makale/1207

Istianyani, A. (2012). Upaya percepatan daya serap lulusan Fakultas Teknik melalui optimalisasi peran bursa kerja khusus UNJ sebagai mitra dari dunia usaha dan industri. In Proceeding of National Conference of APTEKINDO (Asosiasi Pendidikan Teknologi dan Kejuruan Indonesia) (pp. 143-148). Jakarta: Universitas Negeri Jakarta.

Law of Republic of Indonesia No. 20 of 2003 on National Education System (2003).

Pambayun, N. A. Y., \& Wagiran, W. (2014). Kinerja bursa kerja khusus (BKK) SMK Negeri bidang keahlian teknologi dan rekayasa di Kabupaten Sleman. Jurnal Pendidikan Vokasi, 4(2), 246-261. https://doi.org/10.21831/jpv.v4i2.2550

Pavlova, M. (2009). Technology and vocational education for sustainable development: Empowering individuals for the future. Queensland: Springer Science \& Business Media.

Presidential Instruction No. 9 of 2016 on Revitalization program of Vocational High School (VHS) for the improvement of Indonesian human resources' quality and competitiveness (2016). Republic of Indonesia.

Ramadhan, A. N., \& Soenarto, S. (2015). Pengaruh persepsi siswa terhadap faktor-faktor yang mempengaruhi prestasi belajar teori kejuruan siswa SMK. Jurnal Pendidikan Vokasi, 5(3). https://doi.org/10.21831/jpv.v5i3.6485

Regulation of the Minister of Education and Culture No. 34 of 2018 on the national standard of education in Vocational High School (2018). Republic of Indonesia.

Regulation of the Minister of Manpower No. 39 of 2016 concerning manpower placement (2016). Republic of Indonesia.

Ridawati, H. (2017). Evaluasi program Bursa Kerja Khusus (BKK) berdasarkan goaloriented evaluation model di SMKN 3 Salatiga. Thesis. Universitas Kristen Satyawacana.

Sarwono, S. W. (2012). Psikologi remaja. Jakarta: PT. Raja Grafindo Persada.

Septiningrum, I. (2017). Kinerja Bursa Kerja Khusus (BKK) dalam membantu penyaluran kerja lulusan kompetensi keahlian Administrasi Perkantoran SMK Negeri 1 Yogyakarta. Thesis. Universitas Negeri Yogyakarta.

Slameto, S. (2010). Belajar dan faktor-faktor yang mempengaruhinya. Jakarta: Rineka Cipta.

Sudira, P. (2016). TVET abad XXI: Filosofi, teori, konsep, dan strategi pembelajaran vokasional. Yogyakarta: UNY Press.

Yazid, T. P., \& Ridwan, R. (2017). Proses persepsi diri mahasiswa dalam berbusana muslimah. Jurnal An-Nida': Jurnal Pemikiran Islam, 41(2), 193201. 